\title{
NOTES ON THE DISTRIBUTION OF TUCUXI, SOTALIA FLUVIATILIS (CETACEA: DELPHINIDAE), IN ECUADORIAN AMAZONIA
}

\author{
Galo Zapata-Ríos ${ }^{1, *}$ and Víctor Utreras B. ${ }^{1,2}$
}

Sotalia fluviatilis, commonly known as tucuxi, is widely distributed in the main tributaries of the Amazon Basin in northern Brazil, Peru, Ecuador, and Colombia (Borobia et al., 1991; Jefferson et al., 1993; da Silva and Best, 1996; Nowak, 1999). In Ecuador, tucuxi is an elusive species with apparently low population densities (Denkinger, 2001) and evidence of its geographical distribution is patchy (Utreras et al., 2001). Little is known about its habitat requirements, movement patterns or population dynamics (Utreras, 1996; Utreras et al., 2001). This paper reports occasional sightings of tucuxis made by different observers, including the authors, during the last 15 years in the Ecuadorian Amazon, in an attempt to add new information on the occurrence of the species in Ecuadorian waters.

In Ecuador, S. fluviatilis has been recorded to date as far north as the Putumayo River along the Colombian border. The southernmost records include the Morona and Mangosiza Rivers, near the southeastern Peruvian border. The majority of records come from the Putumayo, Aguarico, Napo and Yasuní Rivers (Table 1). This, however, can reflect higher observation effort in those areas. S. fluviatilis records for

Table 1. Records of Sotalia fluviatilis in the Ecuadorian Amazon.

\begin{tabular}{|c|c|c|c|c|}
\hline RIVER & LATITUDE/LONGITUDE & DATE & $n$ INDIV. & OBSERVER / SOURCE \\
\hline \multirow[t]{6}{*}{ Putumayo } & $0^{\circ} 08^{\prime} 02^{\prime \prime} \mathrm{N}, 75^{\circ} 51^{\prime} 25^{\prime \prime} \mathrm{W}$ & Apr., 1997 & 7 & Galo Zapata-Ríos \\
\hline & 0॰14'11"N, 75॰59'43"W & Oct., 1997 & 3 & Galo Zapata-Ríos \\
\hline & $0^{\circ} 08^{\prime} 02^{\prime \prime} \mathrm{N}, 75^{\circ} 51^{\prime} 25^{\prime \prime} \mathrm{W}$ & Jan., 1998 & 4 & Galo Zapata-Ríos \\
\hline & 0॰01'12"S, 75॰32'00"W & May, 1998 & 2 & Galo Zapata-Ríos \\
\hline & $0^{\circ} 08^{\prime} 02^{\prime \prime} \mathrm{N}, 75^{\circ} 51^{\prime} 25^{\prime \prime} \mathrm{W}$ & Nov., 1998 & 3 & Galo Zapata-Ríos \\
\hline & 0॰14'11"N, 75॰59'43"W & Feb., 1999 & 5 & Galo Zapata-Ríos \\
\hline Güeppí & 0॰07'46"S, 75॰16'20"W & Mar., 1998 & 3 & Galo Zapata-Ríos \\
\hline \multirow[t]{2}{*}{ Cuyabeno } & 0॰05'32"S, 76¹0'34"W & Feb., 1993 & 10 & Jens Svenning \\
\hline & 1'05'32"S, 76¹0'34"W & May., 1988 & 5 & Felipe Campos \\
\hline \multirow[t]{5}{*}{ Aguarico } & 0॰15'01"S, 75॰51'05"W & Jan., 1992 & 2 & Víctor Utreras B. \\
\hline & 0॰33'20"S, 75²8'39"W & Aug., 1994 & 2 & Víctor Utreras B. \\
\hline & 0³8'04"S, 75¹5'40"W & Sep., 1997 & 2 & Denkinger, 2001 \\
\hline & 0॰38'04"S, 75॰15'40"W & 1992 & 2 & Herman et al., 1996 \\
\hline & 1॰38'04"S, 75॰15'40"W & Oct., 1997 & 2 & Denkinger, 2001 \\
\hline Pañayacu & 0'25'42"S, 7606'01"W & 1993 & 2 & Norby López \\
\hline \multirow[t]{3}{*}{ Napo } & 0॰54'01"S, 75²5'26"W & Sep., 2000 & 4 & Víctor Utreras B. \& Robert Williams \\
\hline & 0॰55'10"S, 75²3'18"W & Jan., 2003 & 2 & Víctor Utreras B. \\
\hline & 0²7'43"S, 7658'55"W & Apr., 2003 & 1 & Fausto Cornejo \\
\hline \multirow[t]{2}{*}{ Tiputini } & 0॰40'58"S, 76²3'18"W & Aug., 1995 & 2 & Henrik Balslev \& Pamela Hall \\
\hline & 0॰45'16"S, 75॰46'44"W & Jan., 2001 & 3 & Víctor Utreras B. \\
\hline \multirow[t]{4}{*}{ Yasuní } & 0॰59'35"S, 75²7'03"W & May., 2000 & 2 & Robert Williams \\
\hline & 0॰59'27"S, 75²5'42"W & Sep., 2000 & 2 & Víctor Utreras B. \& Robert Williams \\
\hline & 0॰55'50"S, 75²3'02"W & Feb., 2001 & 1 & Víctor Utreras B. \\
\hline & 0॰57'19"S, 75²4'14"W & Jan., 2003 & 2 & Víctor Utreras B. \\
\hline Pastaza & 2०32' 25"S, 7649'43"W & Aug., 1998 & 2 & Víctor Utreras B. \\
\hline Mangosiza & 2॰52'30"S, 77॰41'47"W & Jan., 2003 & 3 & Galo Zapata-Ríos \\
\hline Morona & 2॰45'32"S, 77॰34'49"W & Dec., 2002 & 2 & Galo Zapata-Ríos \\
\hline Cushuimi & 2。45'56"S, 77॰39'27"W & - & - & Tuntiak Katán \\
\hline \multirow[t]{2}{*}{ Cangaime } & 2०36'12"S, 77॰28'38"W & - & - & Tuntiak Katán \\
\hline & 2॰44'19"S, 77²9'11"W & Apr., 2003 & 2 & Galo Zapata-Ríos \\
\hline Makuma & 2०31'05"S, 77॰38'10"W & - & - & Tuntiak Katán \\
\hline Wichimi & $2^{\circ} 43^{\prime} 47^{\prime \prime S}, 77^{\circ} 23^{\prime} 47^{\prime \prime} \mathrm{W}$ & - & - & Tuntiak Katán \\
\hline
\end{tabular}

\footnotetext{
${ }^{1}$ Wildlife Conservation Society - Ecuador Program. San Francisco 441 y Mariano Echeverría. P.O. Box 17-21-168. Quito, Ecuador. ${ }^{2}$ E-mail: vmub@wcsecuador.org

"Corresponding author, e-mail: gazr@wcsecuador.org
} 
Ecuador, as included in this article, are more numerous for the Napo and Morona River Basins, with a single record of two individuals from the Pastaza River (Figure 1). According to some observers, in some localities tucuxi presence is occasional (e.g., Napo, and Tiputini Rivers) compared to sightings made in rivers where the species is seemingly abundant and observed on a frequent basis by local people (e.g., Putumayo, and Morona Rivers).

S. fluviatilis has been listed under CITES Appendix I since 1982 and it is included in the "data deficient" category by IUCN (IUCN, 2000; CITES, 2003). Its current conservation status in Ecuador is uncertain given the lack of information on its biology and population status, however it has nevertheless been categorized as an "endangered species" (Tirira, 2001). Therefore, we recommend that medium- to long-term population studies be conducted in order to provide an assessment based on scientific data.
Tucuxis may be adversely affected by water pollution caused by oil industry activities (Denkinger, 2001), increased use of outboard motors, and illegal fishing using explosives (Utreras et al., 2001). The river basins inhabited by the species are also threatened by intense forest disturbance, and human population growth.

Indigenous peoples regard S. fluviatilis as sacred animals, and believe that they will rescue a drowning person to the river shore. This species have different names in the Ecuadorian Amazon and are known as Apup by the Shuar, Bo'to by the Cofán, Uhuara by the Huaorani, Okó'wî by the Siona and Bucyo by the Kichwa (Zapata-Ríos, 2000).

The long-term survival of S. fluviatilis, in Ecuador, depends on the environmental quality of rivers and lakes. In order to take appropriate conservation and management actions, issues should be analyzed and addressed on a basin-wide scale.

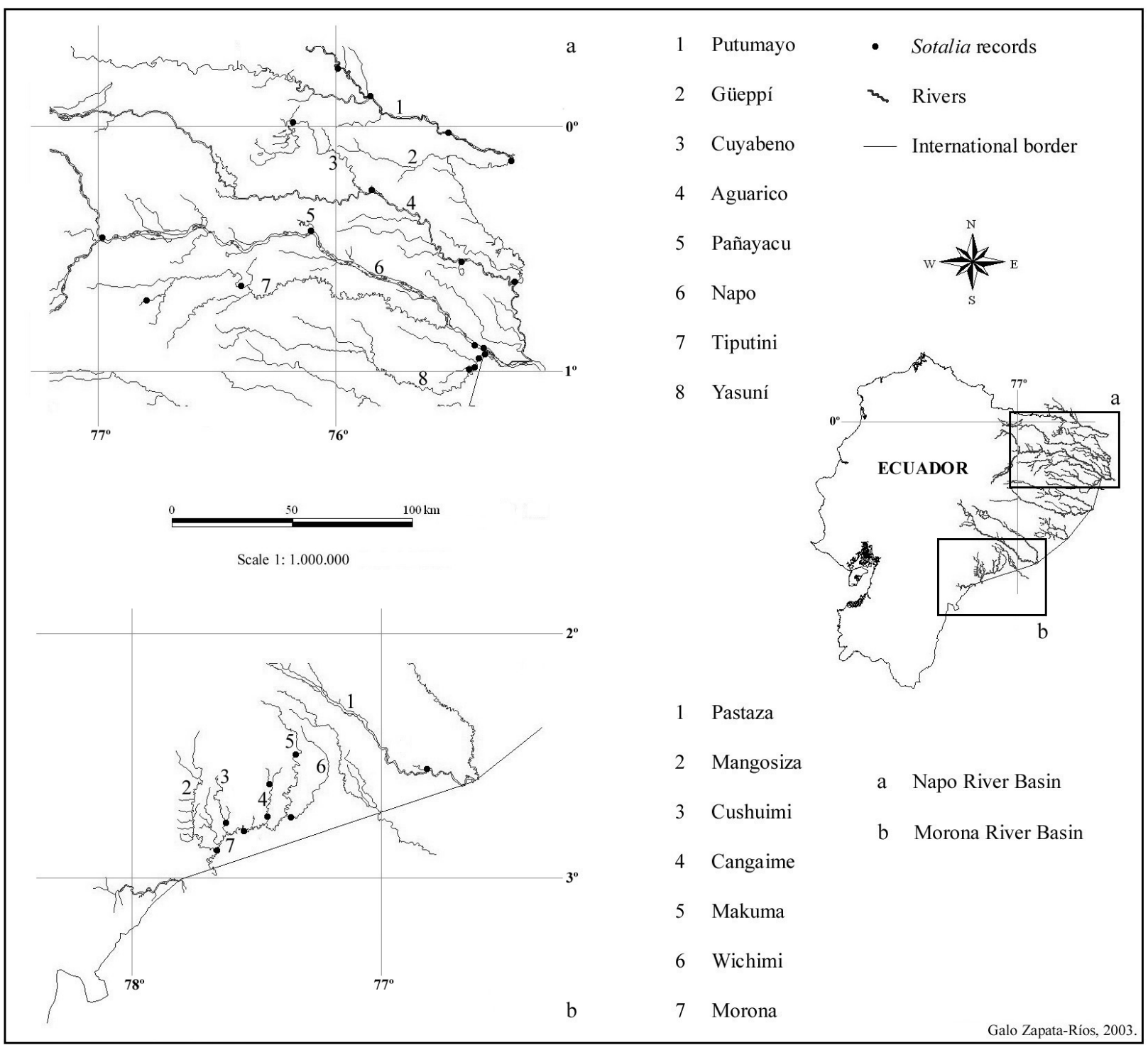

Figure 1. Map of the Ecuadorian Amazon showing Sotalia fluviatilis records in the Napo (a) and Morona (b) River Basins (numbers in the map show rivers where this species has been recorded). 
favor checar o título resumido do cabeçalho!

\section{Acknowledgements}

Authors' sightings from 2000 to 2003 were made while carrying out fieldwork for the Wildlife Conservation Society - Ecuador Program with the support of USAID, Care International, and The Liz Claiborne and Art Ortenberg Foundation. We would like to thank the various people listed in Table 1 for the information provided. Jeffrey P. Jorgenson and Fernando Rosas made useful comments on an early draft of this article. Mônica Borobia, Wyb Hoek and the editors reviewed and made suggestions to improve this note.

\section{References}

Borobia, M., Siciliano, S., Lodi, L. and Hoek, W. (1991) Distribution of the South American dolphin Sotalia fluviatilis. Canadian Journal of Zoology 69: 1025-1039.

CITES (2003) Species Database. http://www.cites.org/eng/ resources/species.html

Da Silva, V. and Best, R.C. (1996) Sotalia fluviatilis Gervais, 1853. Mammalian Species 527: 1-7.
Denkinger, J. (2001) Demographische Untersuchungen am Amazonasdelphin (Inia geoffrensis) im Cuyabeno Reservat, in Ecuador. Ph.D. Thesis, Universität Bielefeld, Bielefeld Germany.

Herman, L., von Fersen, L. and Solangy, M. (1996) The bufeo (Inia geoffrensis) in the río Lagartococha of the Ecuadorian Amazon. Marine Mammal Science 12: 118-125.

IUCN (2000) Red List of Threatened Species. http:/ / www.iucn.org/ redlist $/ 2000$

Jefferson, T.A., Leatherwood, S. and Webber, M.A. (1993) Marine Mammals of the World. FAO-UNEP, Rome.

Nowak, R. (1999) Walker's Mammals of the World. Johns Hopkins University Press, Baltimore.

Tirira, D. (2001) Libro Rojo de los Mamíferos del Ecuador. SIMBIOE, Quito.

Utreras, V. (1996) Estimación de la Abundancia, Aspectos Ecológicos y Etológicos del Delfin Amazónico Inia geoffrensis geoffrensis (Cetacea: Iniidae) en el Río Lagartococha, Amazonía Ecuatoriana. Tesis de Licenciatura, Pontificia Universidad Católica del Ecuador, Quito.

Utreras, V., Tirira, D. and Denkinger, D.J. (2001) Sotalia fluviatilis, delfín gris de río. Pages 80-81 in Tirira, D. (Ed) Libro Rojo de los Mamíferos del Ecuador. SIMBIOE, Quito.

Zapata-Ríos, G. (2000) Mammals of the Ecuadorian Amazon: the vernacular names. Abya-Yala, Quito. 